\title{
DINAMIKA SOSIAL TERHADAP RENCANA PEMBANGUNAN BANDARA DI DESA TONGGURAMBANG KECAMATAN AESESA KABUPATEN NAGEKEO FLORES PROVINSI NUSA TENGGARA TIMUR
}

\author{
Suwardi A Kadir ${ }^{1}$, Nurlina Subair ${ }^{2}$ dan Abdul Aziz Muslimin ${ }^{3}$ \\ ${ }^{1}$ Pendidikan Sosiologi, Universitas Muhammadiyah Makassar \\ Email: suawardikadir@gmail.com \\ ${ }^{2}$ Pendidikan Sosiologi, Universitas Muhammadiyah Makassar \\ Email: nurlinasubair@unismuh.ac.id \\ ${ }^{3}$ Pendidikan Sosiologi, Universitas Muhammadiyah Makassar \\ Email: abdulasismuslimin@unismuh.ac.id
}

\begin{abstract}
The reaction of the community to the development of the Bandar increases the pace of the economy, development is actually a planned and desired process of change, at least development is generally the will of the community and decisions taken by the leader, this is where the government needs to introduce airport development socialization, especially land certification issues so that the implementation of the pro and contra reaction between the community and the government did not occur. The social dynamics of airport development are very significant in terms of the construction of airports in Tonggurambang Village which is the location of the airport. The existence of the airport also has an influence on the social and economic changes of the surrounding community, especially in the village of Tonggurambang, which has experienced changes in people's livelihoods due to changes in land functions that have only been agricultural land or plantations into airport buildings and limited human resources.
\end{abstract}

Keywords: Social Dynamics and Development.

Abstrak. Reaksi masyarakat terhadap adanya pembangunan Bandar meningkatkan laju perekonomian, pembangunan sebenarnya merupakan suatu proses perubahan yang direncanakan dan dikehendaki, setidaknya pembangunan pada umumnya merupakan kehendak masyarakat dan keputusan yang diambil oleh pemimpin, disinilah perlu pemerintah terkait mengadakaan sosialisasi pembangunan bandara terutama masalah sertifikasi lahan sehingga pada saat pelaksanaannya tidak terjadi reaaksi pro dan kontra antara maasyarakat dan pemerintah. Dinamika sosial terhadap pembangunan bandara sangat signifikan berpengaruh dalam hal pembangunan bandara di Desa Tonggurambang yang menjadi lokasi Bandara. keberadaan Bandara juga memberikan pengaruh terhadap perubahan sosial dan ekonomi masyarakat sekitar, khususnya di desa Tonggurambang yang mengalami perubahan mata pencaharian penduduk karena akibat terjadinya perubahan fungsi lahan yang selama ini hanya berupa lahan pertanian atau perkebunan menjadi lahan bangunan bandara serta terbatasnya sumber daya manusia.

Kata Kunci: Dinamika Sosial dan Pembangunan.

\section{PENDAHULUAN}

Bandar udara Internasional diatur dalam Pasal 256 UU.RI No./2009. Menurut Pasal tersebut Menteri Perhubungan menetapkan beberapa Bandar udara Internasional dengan mempertimbangkan rencana induk nasional Bandar udara, pertahanan dan keamanan negara, pertumbuhan dan perkembangan pariwisata, kepentingan dan kemampuan angkutan udara nasional serta pengembangan ekonomi nasional dan perdagangan luar negeri, di samping pertimbangan dari menteri terkait. Ketentuan lebih lanjut mengenai Bandar Udara Internasional diatur dengan Peraturan Menteri Perhubungan. Namun adanya rencana pembangunan bandara ternyata tidak 
langsung disetujui oleh semua pihak masyarakat yang ada di Desa Tonggurambang. Sampai saat ini dalam proses pelaksanaannya masih ada penolakan dari pihak masyarakat yang akan terkena dampak langsung pembangunan. Masyarakat yang terkena dampak langsung pembangunan bandara yang sebagian besar petani beranggapan bahwa apabila pembangunan bandara terlaksana maka mata pencaharian mereka akan hilang. Di sisi lain ada juga masyarakat yang mendukung pembangunan bandara baru tersebut. Masyarakat yang setuju akan dibangunnya bandara beranggapan bahwa dengan adanya bandara maka kegiatan perekonomian akan tumbuh dan berdampak langsung terhadap pendapatan masyarakat.

Pemerintah Kabupaten Nagekeo, Nusa Tenggara Timur (NTT) tetap akan memperjuangkan pembangunan bandara Surabaya II di daerah tersebut sebagai pintu masuk pariwisata di Flores. Pihak Pemerintah tetap akan melakukan pendekatan kepada masyarakat perihal perencanaan akan di bangunnya sebuah bandara di Desa Tonggurambang Kecamatan Aesesa Kabupaten Nagekeo itu. Bandara yang akan di bangun mempunyai nilai yang sangat strategis yang akan menjadi pintu masuk pariwisata di Flores selain Bandara Labuan Bajo yang ada di Manggrai Barat.

Berkaitan dengan perencanaan dan perumusan peraturan perundang-undangan di bidang pertanahan kiranya relevan untuk mempertanyakan tentang bagaimana dan sejauh mana serta tujuan yang hendak dicapai dalam kewenangan. Negara untuk mengatur peruntukan, penggunaan serta pemeliharaan tanah termasuk mengatur dan menentukan hubungan hukum dan perbuatan hukum mengenai tanah. Sehingga tanah yang mempunyai nilai ekonomis sekaligus fungsi sosial tersebut dapat diperoleh dan dimanfaatkan oleh setiap orang untuk mendukung kegiatan yang diperlukan. Pembangunan.Nasional khususnya pembangunan berbagai fasilitas untuk kepentingan umum memerlukan bidang tanah yang sangat luas.

Pembangunan bandara merupakan pintu masuk terhadap suatu wilayah dan menjadi penghubung antar wilayah satu dengan wilayah lainnya. Sesuai Keppres No.15 tahun 2002 bahwasanya untuk mendistribusikan sebagian beban penumpukan aktivitas dari pusat kota ke wilayah lain, serta mengakselerasikan perkembangan kota maka salah satu cara dalam perwujudannya adalah dengan cara memindahkan bandara yang terdapat di pusat kota ke daerah lain di mana daerah tersebut merupakan daerah penyangga ibukota. Harapan pemerintah kota Nagekeo secara fisik dapat diterjemahkan bahwa pembangunan bandar udara Tonggurambang merupakan kegiatan pelayanan yang kebanyakan berwujud perekonomian. Fungsi bandara yaitu sebagai titik fokal/orientasi ke bangkitan ekonomi untuk wilayah sekitarnya.

Keberadaaan bandara dalam hal ini merupakan titik kumpul manusia. Berkumpulnya sejumlah manusia di dalam bandara akan melahirkan iklim ekonomi dari kelompok pedagang untuk memperoleh keuntungan dari potensi keberadaan konsumen dan pengguna bandara Tonggurambang tersebut. Keberadaan dari kelompok pedagang akan membentuk suatu kawasan perdagangan yang mengisi aktivitas ruang di sekitar bandara tersebut. Bandar udara merupakan salah satu simpul transportasi yang memiliki peranan penting dalam penyelenggaraan transportasi antar moda, khususnya antara moda udara, moda jalan, dan moda rel. Upaya dalam meningkatkan pelayanan operasional suatu bandara perlu didukung oleh sarana angkutan umum yang handal dan berkualitas. Mengacu pada masterplan bandara Tonggurambang, dikarenakan wilayah kota Nagekeo yang luas dan pertumbuhan penduduknya semakin meningkat sehingga kebutuhan akan lahan tempat tinggal pun semakin meningkat pula.

Jika dilihat dari perspektif geografis untuk pilihan lokasi di daerah Kabupaten Nagekeo itu sendiri sebenarnya banyak sekali lahan yang masi kurang dari pemukiman warga, salah satunya Mbay kiri. Desa Tonggurambang ini dianggap cocok karena memang sangataman untuk keselamatan penerbangan ketika pesawat hendak take off atau landing, karena posisinya yang strategis. Pada dasarnya rencana pembangunan Bandara Internasional yang akan berlokasi di Desa Tonggurambang harus lebih mempertimbangkan beberapa faktor seperti, faktor komunikasi, sumber daya, sikap pelaksana dan faktor struktur birokrasi. Pemerintah sebisa mungkin juga memperhatikan kesejahteraan masyarakat di sekitar lokasi Bandara. 


\section{METODE PENELITIAN}

Jenis penelitian yang digunakan dalam penelitian ini adalah peneitian kualitatif deskriftif yang bertujuan memahami realitas fenomena dinamika social terhadap pembangunan bandara. Teknik pengumpulan data yang digunakan dalam penelitian yaitu observasi, wawancara dan dokumentasi, kemudian dianalisis melalui tahapan pengumpulan data (data collection), reduksi data (data reduction), penyajian data (display data), penarikan kesimpulan (conclusion) dan menggunakan teknik keabsahan data triangulasi sumber, teknik, dan waktu.

\section{HASIL DAN PEMBAHASAN}

\section{Reaksi Masyarakat Terhadap Rencana Pembangunan Bandara}

Desa Tonggurambang merupakan wilayah penyangga atau hinterland dari kota yang lain, dengan adanya pembangunan bandara baru di daerah tersebut, maka desa Tonggurambang terkena dampak terhadap perkembangan ekonomi maupun perubahan tata guna lahan (fungsi lahan) di sekitarnya. Bandara Tonggurambang merupakan bekas persawahan yang masih produktif sehingga oleh pihak angkasa pura II melakukan pembebasan lahan di daerah tersebut untuk dijadikan bandara yang baru. Perencanaan pembangunan bandara Tonggurambang sebenarnya telah diusulkan dan direncanakan sejak tahun 2008, akan tetapi proses pembangunannya dimulai pada tahun 2009 dengan tahap pembebasan lahan oleh pihak angkasa pura II, akan tetapi pembebasan lahan yang terjadi pada waktu itu tertunda karena masyarakat desa Tonggurambang belum memberikan pembebasan lahan secara menyeluruh, karena sebagian lahan masih digunakan oleh masyarakat desa Tonggurambang Oleh karena itu tentunya ada reaksi pro dan kontra yang mengikuti pembangunan Bandara Surabaya II tersebut terutama dalam hal pembebasan lahan yang akan digunakan untuk pembangunan bandara. sebagaimana yang dijelaskan dibawah ini :

\section{a. Reaksi Pro}

Pembangunan Bandara Surabaya II secara umum dapat dikatakan bahwa reaksi pro yang terjadi di dalam masyarakat di sekitar wilayah pembangunan Bandara Surabaya II terutama di Desa Tonggurambang merupakan wujud aspirasi dari masyarakat sekitar dan melihat potensi yang besar dalam hal meningkaatkan perekonomian dan kesejahtraan masyarakat. Walaupun ada pro dan kontra, akan tetapi lebih banyak masyarakat yang pro terhadap proyek pembangunan Bandara Surabaya II di desa Tonggurambang karena sebagian dari mereka yakin bahwa pembangunan ini akan memberikan sesuatu yang baik ke depannya dalam kehidupan masyarakat sehingga perlu melakukan sosialisasi terhadap masyarakat terkait teknis jalannya pembangunan bandara. Seperti hasil wawancara dengan (AB), bahwa:

"Pada dasarnya setiap pembangunan yang besar terdapat pasti sebuah masalah, apa lagi ini soal bandara yang merupakan bangunan yang begitu besar dan pasti membutuhkan lahan yang sangat luas, akan tetapi otomatis juga ada hal positif yang terjadi kepada masyarakat terhadap pembagunan ini, misalnya adanya lowongan pekerjaan yang terbuka yang dikhususkan masyarakat sekitar pembagunan bandara" (Hasil Wawancara 09 Oktober 2018).

Hasil wawancara dengan (AB) senada dengan apa yang diungkapkan oleh (SW), bahwa :

"Adanya pembangunan Bandara Surabaya II sangat berpengaruh pada kehidupan masyarakat Desa Tonggurambang karena dengan adanya pembangunan bandara ini otomatis masyarakat akan merubah pola pikirnya pada saat pembanguan, sehingga masyarakat tidak hanya bekerja di sawah dan kebun saja" (Hasil Wawancara 05 Oktober 2018).

Berdasarkan hasil wanwancara dengan informan diatas, penulis dapat menyimpulkan bahwa dengan adanya pembangunan Bandara Surabaya II tentunya tingkat aktivitas yang terjadi di wilayah tersebut meningkat sangat drastis sehingga akan mempengaruhi sosial ekonomi dari wilayah tersebut. Pembangunan Bandara Surbaya II dilakukan dalam rangka meningkatkan manfaat sumber daya lahan di Desa Tonggurambang yang ditinjau dari sudut lingkungan dan sosial ekonomi dengan 
cara reklamasi, hal ini umumnya terjadi karena semakin tingginya tingkat populasi manusia khususnya di kawasan pesisir, sehingga pemerintah perlu memberikan solusi dari daerah yang awalnya relatif tidak berguna menjadi daerah yang lebih prouktif. Seperti yang dikemukakan oleh (WW), bahwa :

"Hadirnya pembangunan Bandara Surabaya II diharapkan dapat meningkatkan sumber daya lahan yang ada di kawasan desa Tonggurambang, Pemerintah kabupaten Nagekeo merupakan sebagai penanggung jawab pembangunan bandara sangat berperan aktif dalam pembangunan infrastruktur bandara tersebut walaupun ada beberapa kendala akan tetapi hal tersebut tidak mengurangi niat masyarakat untuk berperan aktif dalam pembangunan bandara Surabaya II ini. (Hasil Wawancara 03 oktober 2018)

Hasil wawancara dengan informan tersebut peneliti menyimpulkan bahwa pembangunan bandara sangat penting di daerah Kabupaten Ngekeo khususnya di Desa Tonggurambang. Adanya pembangunan Bandar Udara Suarabaya II dapat meningkatkan laju perekonomian, pembangunan sebenarnya merupakan suatu proses perubahan yang direncanakan dan dikehendaki, setidaknya pembangunan pada umumnya merupakan kehendak masyarakat dan keputusan yang diambil oleh pemimpin, disinilah perlu pemerintah terkait mengadakaan sosialisasi pembangunan bandara terutama masalah sertifikasi lahan sehingga pada saat pelaksanaannya tidak terjadi pro kontra antara maasyarakat dan pemerintah.

\section{b. Reaksi Kontra}

Rencana pembangunan tentunya harus ada pihak yang dikorbankan demi tercapainya sebuah proses pembangunan, dalam kasus pembangunan Bandar Udara Surabaya II di desa Tonggurambang tentunya ada lahan yang digunakan untuk pembangunan yang berasal dari lahan yang dimiliki oleh masyarakat desa Tonggurambang, oleh karena itu ada reaksi kontra yang dialami dalam proses rencana pembagunan Bandar Udara Suraabaya II di desa Tonggurambang. Soal pembebasan lahan, pemerintah harus memberikan nominal yang sesuai agar masyarakat tidak keberatan memberikan lahan mereka untuk dijadikan lahan pembangunan baik itu pembanguan bandara itu sendiri ataupun infrastruktur yang menunjang bandara tersebut. Dengan adanya sosialisasi dan nominal yang diberikan sesuai porinya tentunya akan meredam reaksi kontra yang muncul dari masyarakat terkait rencana pembangunan Bandar Udara Surabaya II.

Permasalahan ganti rugi lahan merupakan salah satu permasalahan yang selalu timbul pada saat rencana pembangunan bandara dalam hal ini perlu adanya kesepahaman pemikiran anatar pemerintah dengan masyarakaat sebagai pihak yang memiliki tanah pemerintah juga harus memberikan pengertian kepada masyarakat yang memiliki lahan agar dapat mengambil keputusan yang menyenangkan kedua pihak dalam kasus pembebasan lahan disekitar lokasi pembangunan bandara. Permasalahan yang muncul pada umumnya disebabkan oleh kurangnya sosialisasi informasi mengenai berapa besar ganti rugi lahan yang diinginkan oleh masyarakat, inilah yang menjadi pangkal masalah disekitar pembanguan bandara. Seperti hasil wawancara oleh salah satu informan (AD), bahwa :

"Sebenarnya kita sangat mendukung kalau soal ada pembangunan didaerah kami, namun hanya saja ada lahan sawah kami yang terkena dampak pembangunann sehingga kami perlu ada kompensasi lahan, atau ganti rugi lahan oleh pemerintah, ganti rugi inilah selalu menjadi persoalan yang dirasakan pada masyarakat, informasi dan sosialisasi pemerintah sangat berpengaruh pada masyarakat desa" (Hasil Wawancara 17 Oktober 2018)

Senada dengan hasil wawancara (AD) dengan informan (JI), bahwa :

"Permasalahan inilah selalu muncul pada setiap pembangunan, perlu adanya kesepakatan besama antara pemerintah dan masyarakat, dan harus ada kejelasan oleh pemerintah mengenai lahan yang terkena dampak peembangunan bandara, dan harus juga 
jelas memberikan nominal atau jaminan hidup kepada masyarakat sekitar". (Hasil Wawancara 12 oktober 2018).

Berdasarkan hasil wawancara diatas peneliti menyimpulakan bahwa proses pembebasan lahan selalu menjadi penghambat pembangunan bandara, masyarakat desa Tonggurambang umumnya menginginkan ganti rugi lahan yang sesuai harga atau nilai tanah atau setidaknya ada jaminan yang setara untuk kedepannaya, sehingga masyarakat sekitar tidak merasa dirugikan. pemrintah perlu mendengar aspirasi dari masyarakat dan mempertimbangkan apa yang menjadi keinginan masyarakat yang memiliki lahan pertanian. Seperti apa yang diungkapkan salah satu informan (IS), bahwa :

"Dalam kasus pemebasan lahan disekitar lokasi bandara terdapat masalah yang muncul karena disebabkan oleh kuranngnya sosialisasi informasi mengenai berapa besaran ganti rugi dari pemerintah serta berapa ganti rugi yang diinginkan oleh masyarakat. Inilah yang menjadi inti permaslahan yang terjadi dimasyarakat desa Tonggurambang mengenai pembangunan bandara." (Hasil Wawancara 04 November 2018)

Dari pernyataan diatas peneliti menyimpulkan bahwa sosialisasi yang berhubungan dengan pembangunan bandara, harusnaya cukup jelas dan sampai kepada masyarakat secara umum. Masyarakat desa Tonggurambang pada umumnya menginginkan gati rugi yang sesuai dengan harga nilai lahan yang dimiliki seehingga masyarakat sekitar sebagai pihak yang memliki tanah tidak merasa dirugikan dengan pembangnan bandara. Proses pembebasan lahan inilah yang menjadi kontra sehingga pemerintah perlu mendengarkan aspirasi dari masyarakat yang memiliki lahan tersebut, maka dari itu perlu informasi dan sosialisasi kepada masyarakaat mengenai rencana peembangunan bandara desa Toggurambang, dengan melakukan pendekatan kepada masyarakat berguna untuk membuat masyarakat tidak merasa bahwa pemerintah berada dipihak yang merugikan masyarakat atau memanfaatkan masayarakat desa Tongguramang.

\section{Dinamika Sosial Terhadap Rencana Pembangunan Bandara}

Dinamika merupakan keseluruhan perubahan dari seluruh komponen masyarakat dari waktu ke waktu. Dinamika sosial dan budaya memberikan dampak pada juga pada pengelolaan hutan, lahan, dan lingkungan yang ada pada suatu lingkup masyarakat. Peningkatan jumlah penduduk yang semakin banyak mengakibatkan berkurangnya luas kepemilikan lahan pertanian yang dimiliki oleh setiap keluarga, sehingga memberikan dampak pada masyarakat agar melakukan penyesuaianpenyesuaian dengan lingkungannya. Penyesuaian dan pergeseran yang terjadi pada suatu masyarakat bukan pada aturan-aturan yang berlaku pada masyarakat tersebut, akan tetapi pada obyek pelaksana dari aturan dalam masyarakat itu sendiri, yakni individu-individu atau kelompok sosial yang berada pada lingkungan tersebut.

Pembangunan Bandar Udara Surabaya II di desa Tonggurmbang sebenarnya merupakan suatu proses perubahan yang direncanakan dan dikehendaki, setidaknya pembangunan pada umumnya merupakan kehendak masyarakat yang terwujud dan keputusan-keputusan yang diambil oleh para pemimpin. Yang kemudian disusun dalam suatu perencanaan yang selanjutnya dilaksanakan. Pembangunan merupakan yang terus-menerus kemajuan dan perbaikan mmengarah pada suatu tujuan yang ingin dicapai. Desa Tonggurambang merupakan salah satu daerah yang akan mengalami dinamika sosial terhadap pembangunan bandara seperti di kemukakan oleh (AB), bahwa :

"Rencana pembangunan bandara sangat berengaruh karena masyarakat akan mengambil keuntungan dengan menjual tanah yang berada di sekitar bandara Tonggurambang, mereka dengan harga yang cukup tinggi, sehingga masyarakat yang tadi hanya mengandalkan lahan pertanian kini masyarakat dapat memiliki keuntugan yang lebih tinggi, tetapi ini hanya diidapatkan sekali saja, maka dari itu kita harus merubah pola pikir untuk kerja, setelah menjual lahan kita akan kemana" (Hasil Wawancara, 10 Oktober 2018). 
Senada perkataan $(A B)$ menurut salah satu pernyataan informan yaitu (WW), bahwa:

"Masyarakat Desa Tonggurambang akan mengalami perubahan yang sangat signifikan dengan adanya pembangunan bandara, kini masyarakat Desa Tonggurambang tidak hanya mengandalkan satu mata pencaharian yaitu bertani tapi kini mereka bisa mengambil keuntungan dengan berbisnis di sekitar bandara Tonggurrambang, tetapi inipun perlu bantuan yang sangat memadai dari peemerintah ketika lahan pertanian kami diserahkan untuk pembangunan bandara" (Hasil Wawancara, 03 Oktober 2018).

Dengan adanya pembangunan bandara, masyarakat Desa Tonggurambang bisa bekerja di sekitar pembangunan bandara masyarakat Desa Tonggurambang yang hanya meengandalka lahan persawahan untuk bertani kini mereka bisa bekerja di area bandara, perubahan dari pembangunan bandara benar-benar sangat signifikan dan memberikan dimensi pembangunan yang berbeda pada Desa Tonggurambang. Seperti yang di kemukakan oleh (MY) bahwa:

"Pembangunan bandara pada Desa Tomggurambang memberikan kontribusi yang positif dalam kehidupan masyarakat walaupun hal tersebut memerlukan proses yang cukup panjang tetapi kedepannya daerah ini akan semakin maju karena meakukan pembangunan" (Hasil Wawancara, 25 Oktober 2018).

Senada dengan perkataan (MY) menurut salah satu pernyataan informan yaitu (SW), bahwa :

"Saya berharap dengaan keberadaan bandara memberikan konstribusi yang positif pada masyarakat Desa Tonggurambang yang mampu memberikaan perubahan kecil pada masyarakat itu sendiri karena pembangunan merupakan kemajuan pada perbaikan yang mengarah pada tujuan yang ingin dicapai" (Hasil Wawancara 05 Oktober 2018).

Berdasarkan hasil wawancara dengan informan diatas menunjukan bahwa pembangunan sangat berpengaruh dalam kehidupan masyarakat khususnya di Desa Tonggurambang disamping adanya perubahan yang terjadi secara fisik ternyata keberadaan bandara juga berpengaruh terhadap perubahan sosial dan ekonomi masyarakat sekitar khususnya Desa Tonggurambang yang mengalami perubahan mata pencaharian pennduduk tersebut ditandai dengan berkurangnya lahan pertanian yang dapaat menyebabkan bergesernya mata pencaharian penduduk dari sektor lainnya mata pencaharian masyarakat Desa Tonggurambang pada awalnnya bertani namun dengan adanya pembangunan bandara masyarakat benar-benar mengalami perubahan.

Adanya pembangunan bandara ini potensi terhadap peningkatan pengangguran pada wilayah desa Tonggurambang sangat besar karena sebagian besar penduduknya yang memiliki mata pencaharian dari sektor pertanian akan kehilangan mata pencaharian utama. Kultur masyarakat setempat yang masih kental dengan pola masyarakat agraris akan sangat-sangat sulit bagi masyarakat agraris untuk berpindah pola ke industri ataupun ke pekerjaan lain karena sumber daya manusia yang kurang. Apalagi dengan tingkat pendidikan rata-rata di desa tersebut yang masih sangat rendah. Sehingga pesimis kalau kelak masyarakat yang terusir akan ikut menikmati pembangunan bandara tersebut. Seperti apa yang diungkapkan oleh informan (AD), bahwa :

"Masyarakat pada umumnya tidak keberatan jika tanah kami digunakan sebagai pembangunan Bandara tetapi masyarakat juga mengharapkan adanya ganti rugi yang sesuai dengan nilai dari tanah ata jaminan kedepannya sehingga kedua belah pihak tidak ada yang merasa dirugikan, kemudian kami juga yang bekerja seebagai petani pasti terkendala kedepannya walau ada lapangan kerja terbuka tetapi tingkat pendidikan kami rendah karena kami hanyalah petani biasa saja" (Hasil Wawancara 17 Oktober 2018).

Senada perkataan (AD) menurut salah satu pernyataan informan yaitu (IS), bahwa :

"Kami sebagai masyarakat yang tergolong miskin, ketika pemerintah betul jadi membangun bandara didesa ini kami setuju saja asal ada ganti rugi atau kami disediakan lapangan pekerjaan yang berjangka panjang, karena mengapa demikian, jika pembangunan bandara ini benar-benar selesai bakalan banyak lagi lahan yang digunakan pembangunan 
misalnya akses jalanan, perumahan, kantor atau bahkan bangunan yang lainnya. Dengan adanya pembangun tersebut bisa-bisa kita masyarakat desa disini bakalan terusir atau berpindah tempat karena akibat sumber daya manusia kita terbatas dan menyimpitnya lahan pertanian akibat pembangunan. (Hasil Wawancara 4 November 2018).

Berdasarkan hasil wawancara diatas peneliti menyimpulkan bahwa permasalahan dari bidang lingkungan juga akan memberikan perubahan terhadap rusaknya lahan hijau dan kemungkinan tingkat polusi diakibatkan oleh pembangunan yang ditimbulkan dengan adanya pembangunan bandara ini. Hal ini juga memberikan perubahan terhadap sosial dan kultural masyarakat yang ratarata memiliki tingkat pendidikan rendah dan sosialisasi yang dilakukan pemerintah daerah setempat yang telah memberikan sosialisasi dinilai memiliki kebohongan tersendiri dikarenakan banyaknya hal-hal yang tidak transparan.

Interaksi antar wilayah tercermin pada keadaan fasilitas transportasi serta aliran orang, barang, maupun jasa. Transportasi merupakan tolok ukur dalam interaksi keruangan antar wilayah dan sangat penting peranannya dalam menunjang proses perkembangan suatu wilayah. Wilayah dengan kondisi geografis yang beragam memerlukan keterpaduan antar jenis transportasi dalam melayani kebutuhan masyarakat. Pada dasarnya, sistem transportasi dikembangkan untuk menghubungkan dua lokasi guna lahan yang mungkin berbeda untuk kesejahteraan masyarakat. Seperti hasil wawancara dengan informan (MAM) mengatakan bahwa :

"Pembangunan era modern ini sangat dibutuhkan perubahan sosial dan modernisasi pada masyarakat desa yang akan memberikan dampak positif dan perubahan pada masyarrakat itu sendiri, pembangunan merupakan kemajuan pada masyarakat berkembang dengan pembangunan dapat memberi pembaharuan pada masyarakat tradisional, masyarakat desa Tonggurambang sebagian besar menginginkan adanya pembangunan bandara ini yang dapat merubah pola pikir masyarakat, karena kemajuan pada masyarakat diera modern ini sangat berpengaruh. Saya berharap pembagunan bandara ini akan memberi dampak yang sangat baik kedepannya khususnay masyarakat disini kesadaran sangat diperlukan akan adanya pemabangunan bandara.(Hasil Wawancara 9 November 2018)

Berdasarkan pernyataan diatas membuktikan bahwa pentingnya pembaharuan pada masyarakat yang merujuk pada pembangnan memerlukan waktu yang panjang untuk mencapai tahap yang lebih maju karena modernisasi dan perubahan sosial sangat penting dalam laju kesejahtraan masyarakat dalam pembangunan bandara surabaaya II khususnya masyarakat di desa Tonggurambang, nilai fungsi untuk menetapkan dan membentuk pola pikir tentang sesuatu yang ideal dalam kehidupan masyarakat, pada nilai sosial tersebut merupakan tolak ukur dan orientasi bagi setiap individu dalam pergaulan maasyarakat sehingga nilai inilah yang menjadi sumber dinamika pada masyarakat yang seantiasa mengalami pergeseran serta adaptasi atau penyusuaian yang terjadi pada akhirnya akan minumbulkan suatu perubahan sosial.

\section{KESIMPULAN}

Reaksi masyarakat terhadap adanya pembangunan Bandar meningkatkan laju perekonomian, pembangunan sebenarnya merupakan suatu proses perubahan yang direncanakan dan dikehendaki, setidaknya pembangunan pada umumnya merupakan kehendak masyarakat dan keputusan yang diambil oleh pemimpin, disinilah perlu pemerintah terkait mengadakaan sosialisasi pembangunan bandara terutama masalah sertifikasi lahan sehingga pada saat pelaksanaannya tidak terjadi reaaksi pro dan kontra antara maasyarakat dan pemerintah.

Dinamika sosial terhdap Pembangunan Bandara sangat signifikan berpengaruh dalam hal pembangunan bandara di Desa Tonggurambang yang menjadi lokasi Bandara. keberadaan Bandara juga memberikan pengaruh terhadap perubahan sosial dan ekonomi masyarakat sekitar, khususnya di desa Tonggurambang yang mengalami perubahan mata pencaharian penduduk karena akibat terjadinya perubahan fungsi lahan yang selama ini hanya berupa lahan pertanian atau perkebunan menjadi lahan bangunan bandara. 


\section{DAFTAR PUSTAKA}

Akhmad Sopanudin dan Grendi Hendrastono.(2016). Konflik Lahan Pertanian dalam Pembangunan Internasional di Kulon Progo. Yogyakarta: UNY Yogyakarta

Heri Widodo. 2015. Potret pendidikan di Indonesia dan kesiapannya dalam menghadapi masyarakat ekonomi Asia (MEA). Cendekia Jurnal. Volume 13

Iga Serpianing Aroma. 2012. Hubungan Antara Tingkat Kontrol Diri Dengan Kecenderungan Perilaku Kenakalan Remaja. Jurnal Psikologi Pendidikan dan Perkembangan. Volume 1/Nomor 2.

Keppres NO.15 Tahun 2002. Tentang mengakselerasikan perkembangan kota

Khaerunnisa. (2017). Pengaruh Bandar Udara Internasional Sultan Hasanudin terhadap Pengembangan Spasial di Sekitarnya ( Studi Kasus Kelurahan Sudiang Kecamatan Biringkanaya Kota Makassar. Makassar: UIN Makassar

Mahardika Made. (2017). Dinamika Peran Pecalang dalam Menunjang Aktivitas Kepariwisataan di Desa Adat Tuban-Kuta.Vol I (3).53-71.

Mudyaharjo, Redja. 2014. Pengantar Pendidikan Studi Awal Tentang Dasar-Dasar Pendidikan Pada Umumnya Dan Pendidikan Di Indonesia. Jakarta: Rajawali Pers.

Muhlis Madani. 2016. Perilaku Sosial Anak Putus Sekolah. Jurnal Equilibrium Pendidikan Sosiologi. Volume 4/Nomor. 2

Murba.(2017). Studi Implementasi Program Pembangunan Infrastruktur di Desa Erecinnong Kecamatan Bontocani Kabipaten Bone. Makassar: UIN Makassar

Soekanto Soerjono. (2013). Sosiologi sebagai Suatu Pengantar. PT RajaGrafindo Persada: Jakarta.

Sugiyono. (2016). Metode Penelitian, Kuantitatif, Kualitatif dan R\&D. Bandung: Penerbit Alfabeta Bandung.

Undang-Undang Republik Indonesia Nomor 26 Tahun 1989 tentang Penataan Ruang.(2006). Direktorat Jenderal Penataan Ruang.

Undang-Undang NO.5 Tahun 1960 Pasal 6 tentang semua hak atas tanah mempunyai fungsi sosial. 